\title{
How to consider engineered nanomaterials in major accident regulations?
}

\author{
Bernd Nowack*, Nicole C Mueller, Harald F Krug and Peter Wick
}

\begin{abstract}
Major accident regulations aim at protecting the population and the environment from possible accidental releases of chemicals. To achieve this goal, the regulations need to be reassessed in light of the development of new technologies. A currently rapidly growing new technology is nanotechnology, and engineered nanomaterials (ENM) are already produced and used in commercial products. The aim of this work was therefore to evaluate the current knowledge on human and ecotoxicology of ENM and their release and behavior in the environment in the context of major accident prevention. Nano-specific release paths are not to be expected. The established safety standards in the chemical industry are also applicable to ENM, especially the separate storage of flammable solvents and detention reservoirs. The potential of a release to the environment of ENM in powder form is larger than for suspensions; however, it can be minimized by safety measures established for conventional dusts. The considered human toxicology studies show that to date not conclusive enough answers regarding the toxicity of ENM can be made. The effects are dependent not only on the material itself but more on the functionalization, surface reactivity, size, and form. The acute ecotoxicity of ENM seems to be similar to the one of the corresponding microparticles $\left(\mathrm{TiO}_{2}\right)$ or the respective dissolved ions $(\mathrm{Ag}, \mathrm{Zn})$ with the exception of photocatalytically active nano- $\mathrm{TiO}_{2}$, which has an increased toxicity. In order to guarantee that all ENM are included in the existing major accident regulations, different classification options are possible and the advantages and disadvantages are discussed. An important step will be the compulsory inclusion of nano-specific data in the Material Safety Data Sheets that serve as the basic medium to transfer information from the manufacturer to downstream users and authorities. We also call for a regular monitoring of the production and uses for 'high production volume ENM' that could have the largest implications for major accident regulations.
\end{abstract}

Keywords: Nanomaterials; Major accidents; Toxicity; Ecotoxicity

\section{Review}

Introduction

The major accident prevention regulations have the goal to protect the general population and the environment from severe damage due to accidents. In Switzerland, a company has to fulfill the requirements of this regulation if they store compounds on their premises in amounts that surpass the thresholds given in the regulation [1]. The determination of these thresholds is based on an approach, which contrasts the properties of a substance to its amount used within the company. Companies that fall under this regulation have to report an estimation of possible damage and formulate scenarios. If major damage of the general population (more than

\footnotetext{
* Correspondence: nowack@empa.ch

Empa - Swiss Federal Laboratories for Materials Science and Technology, Lerchenfeldstrasse 5, St Gallen 9014, Switzerland
}

ten deaths outside the area of the company) or of the environment cannot be excluded, a quantitative risk estimation based on scenarios has to be prepared. The regulation for major accident prevention only considers major damages of people outside the area of the company and is therefore separate from occupational or consumer protection regulations. It only considers acute effects, and chronic effects or exposure is therefore not included in this scenario.

Nanotechnology is a rapidly growing research and application area with increasing importance for economy, research, and society. In line with the precautionary principle, it is therefore important to investigate possible risks and, if necessary, take measures to protect humans and the environment. In the focus of the risk discussion about nanotechnology are the engineered nanomaterials (ENM) because they can show - compared to larger 
materials - different properties and reactivity. Therefore, they cannot a priori be handled in the same way as larger particles. A separate determination of threshold values and criteria for evaluation is therefore necessary, to account for the new characteristics of ENM.

There is to date no international agreement on how to deal with major accident prevention of ENM. Two reports are available about the fire and explosive properties of ENM [2,3]. The European Commission states that ENM with potential for accidents can be categorized within the Seveso II directive [4]. Several countries have identified the issue of nano-accidents as relevant [5-7]. The English Parliament does not consider nano-specific regulation to be necessary [8].

In a document by the British Standards Institution (BSI) about guidelines for safe handling of ENM, also fundamental measures for preventive actions against accidents are listed [9]. BSI asks companies that work with ENM to develop emergency plans for possible accident scenarios and to list the exact sequence of activities and the measures that need to be taken in case of an accident. All persons that would be involved in such an accident should be informed and trained in handling ENM. Furthermore, measures should be taken to prevent the dissipation of ENM in case of an accident. A report of the OECD about major accidents with ENM is in preparation [10].

The basis for the assessment into the major accident regulation is the material safety data sheet (MSDS). However, there is to date no duty to declare the size of particles or indicate if the material contains a nanosized fraction. Downstream users of compounds therefore receive often no information if a product contains ENM. In many cases, the nano-ingredient does not even reach the required threshold value of $1 \%$ so that it does not even need to be listed in the MSDS. A clear definition what constitutes an ENM is therefore compulsory so that in the future, appropriate designations can be made on the MSDS.

The aim of this work is the assessment of the human toxicity and ecotoxicity of ENM within a major accident in comparison to conventional chemicals. We try to answer the question if for the determination of threshold amounts in the regulation a mass-based approach can be used for ENM and which major accident scenarios need to be considered for ENM. We performed this assessment using four typical ENM that are covering different classes and that are all produced and used in high quantities: nano- $\mathrm{TiO}_{2}$, nano- $\mathrm{ZnO}$, carbon nanotube (CNT), and nano-Ag [11]. We use the Swiss regulation as an example but aim to provide general conclusions.

\section{Release into the environment Potential of ENM for major accidents}

A major accident can happen whenever large amounts of a potentially toxic or reactive substance are present.
This can happen during production and manufacturing as well as during storage and transport. The scenarios for major accidents strongly depend on the used ENM and other chemicals on the same site as well as factors specific for the situation or the site:

- Form of ENM: suspended or as powder

- Presence of flammable or explosive substances (e.g., metallic ENM or organic solvents)

- Type of containment

- Risk of accident during transport

- Safety measures.

In general, we can assume that the potential for major accidents is higher when ENM are present as powder, because they are easier dispersible than suspended ENM [12]. This is due to the fact that in the regulation of major accidents, only the first $30 \mathrm{~min}$ after the accident are of interest and the acute loss of lives or acute damage of the environment is calculated [1]. As water and soil can be purified and thus major consequences in the long-term are not included in the regulatory measures of major accidents, the velocity of dispersibility of powders compared to presuspended ENM plays no important role in our considerations. The potential is also increased by the storage of easily flammable or explosive compounds in the vicinity of the ENM.

Of 25 major accidents or incidents that were reported in 2008 in Germany (no nano-related cases) [13], 11 occurred during production; 4 during handling; 3 during transport; 2 during maintenance; 1 each during storage, decommissioning, and delivery; and 2 with unknown activity. Also, natural hazards such as lightning, earthquakes, or flooding need to be considered as triggers of major accidents, in addition to man-made disasters such as explosions in neighboring factories or airplane crashes $[14,15]$.

The following release scenarios are considered as realistic causes of major accidents for ENM:

- Major accident scenarios during production ENM are produced in very diverse operations [16]. In general, the mechanical-physical top-down approaches can be distinguished from chemical-physical bottom-up approaches. In top-down approaches, ENM are made from larger materials through milling; in bottom-up approaches, ENM are synthesized from atoms, ions, or molecules in a chemical reaction. Milling operations are used for metallic or ceramic ENM with a relatively wide particle size distribution. Chemical-physical approaches have the advantage that the form and size of the particles can be better controlled. 
Possible reactions are precipitation and flame-, plasma-, or gas-phase synthesis.

During milling, a major accident with consequences for the general population can practically be excluded, because in this process, only small amounts (around $100 \mathrm{~kg}$ ) of ENM are used, mainly in aqueous dispersion and of metallic or ceramic ENM; hence, explosions can be excluded. If the process is carried out in organic solvents, then this process needs to be carried out in explosion-proof systems, but due to the small amounts (batch volume of around $100 \mathrm{~L}$ with max 10-kg ENM), no hazard for the population is to be expected. In gas-phase processes, a deflagration and, with easily flammable solvents, a fire hazard cannot be excluded. Nevertheless, a chain of different events is necessary so that release of ENM beyond the fabrication site is possible.

A possible scenario is the explosion of a distillation equipment with subsequent fire during which all ENM in the same fire compartment are released. Depending on the safety measures, amounts stored, and situation-specific conditions, larger amounts of ENM could be released into air or wastewater. We also need to consider that carbon-based ENM could be combusted while metallic ENM could be oxidized.

- Accident scenarios during transport Transport of toxic substances is connected with a rather high risk because traffic accidents are quite common and because easily flammable substances can be released (e.g., fuel). However, the transported amounts of ENM are currently rather small, compared to the total amount of produced material in any size (compare 5 Mio t of produced $\mathrm{TiO}_{2}$ of which only 47,000 $\mathrm{t}$ are nano- $\mathrm{TiO}_{2}$ [17], and this is one of the nanomaterials with the highest production amounts). Although there is currently no nano-specific obligation to label, we propose that the containers for transport of ENM should be labeled as a hazardous material and that containers of the highest safety standards be used. An accident during transport could lead to the spilling of dispersions/powder or a fire through which ENM could reach air, soil, wastewater, or natural waters (Figure 1).

- Accident scenarios during manufacturing and storage

During manufacturing or storage of ENM, fire is a possible hazard, which can result in the release of ENM into air (when stored as powder) as well as into water/wastewater (ENM dispersions). The cause for the accident can be internal (e.g., technical) as well as external factors. Deflagration is possible for metallic ENM, but they are usually stored in dispersion and/or under inert atmosphere. An example is nano-zero-valent iron for which also hydrogen production and the danger of hydrogen explosion need to be considered.

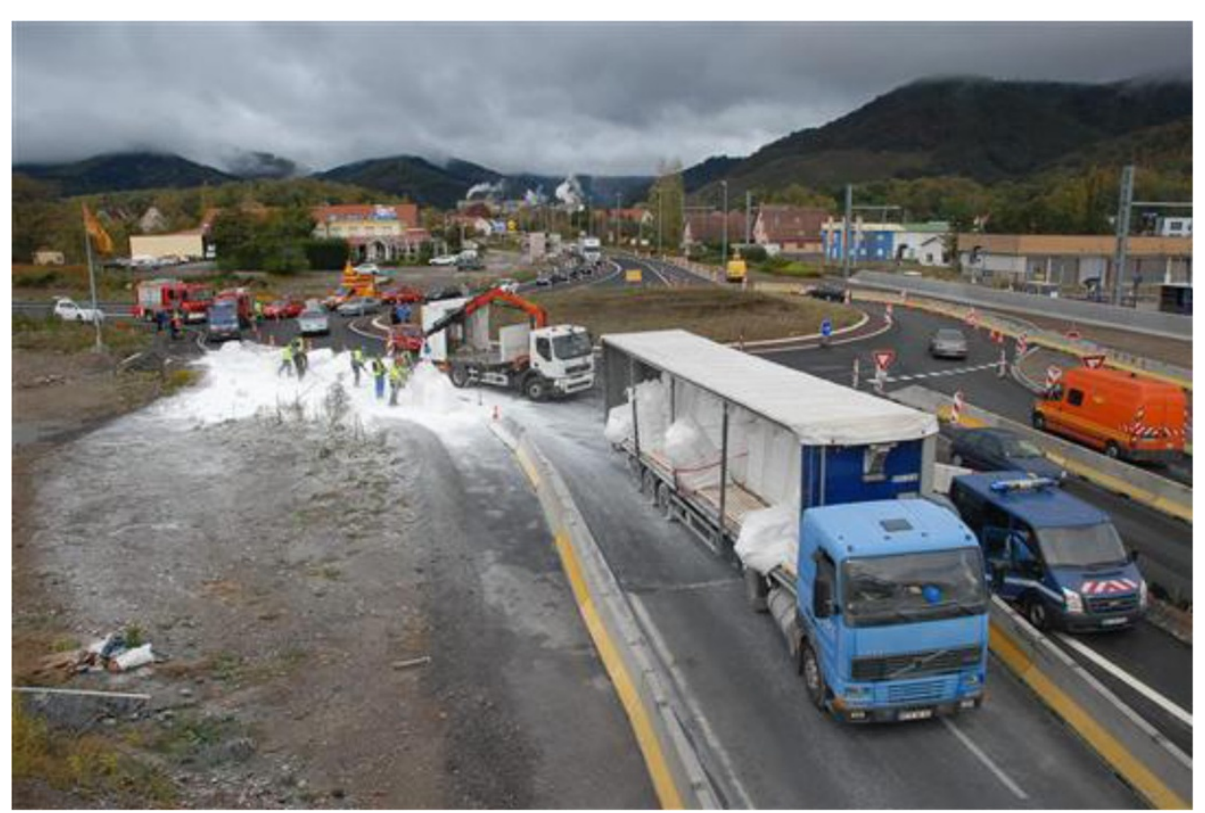

Figure 1 Example of an accident scenario. In 2011, a truck transporting several 750-kg bags of photocatalytic titanium dioxide $\left(\mathrm{TiO}_{2}\right)$ has lost part of its cargo. Since $\mathrm{TiO}_{2}$ is not classified as a hazardous material, workers of the road maintenance department cleaned the road. (Photo from [18]; photographer: Arnaud Viry). 


\section{Release and behavior in the environment}

Based on the scenarios described above, a primary release of ENM into air, water, and soil is possible. A secondary exposure of soil and surface water through deposition from the atmosphere is likely. Also, the indirect contamination of surface water through the effluent of wastewater treatment plants needs to be considered, especially because a shock load of ENM may destroy the removal capacity of the activated sludge phase of wastewater treatment. The secondary pollution of groundwater can be neglected in the case of accidents because particle mobility in soils is generally rather low [19].

To date, no major accidents with ENM are known, and therefore, we do not have any experience with the dissipation behavior of ENM after an accident. Also, models are not yet available that are able to simulate the distribution of ENM in the environment on a local scale [20]. The only available models predict ENM concentrations on a regional scale [21,22]. In these models, the flows of ENM from production, use, and disposal through technical compartments to the environment are predicted and environmental concentrations are obtained assuming well-mixed environmental compartments. Measurements and modeling have been performed for workplace situations [12,23,24]. One study measured and modeled dispersion of ENM during a (purposely made) failure of ventilation in a laboratory-scale flame synthesis reactor [25]. The authors conclude that coagulation of ENM is negligible inside the room [23,25]. The measurements and calculations are restricted to the production room and can therefore not be transferred to environmental conditions during a major accident.

During a major accident, powdered ENM can be released in larger amounts into air. Particles are not volatile and therefore only be released during an explosion or fire. The first elimination step is primarily agglomeration and subsequently deposition of larger particles. Agglomerates with a diameter of $1 \mu \mathrm{m}$ have the longest residence time of particles in the atmosphere [26]. Due to agglomeration, it is not likely that single ENM persist in air [27].

The concentration in air is primarily relevant for human exposure after a major accident. The prevailing weather conditions during the accident play a major role (wind speed, wind direction, precipitation). These conditions cannot be considered in a generic scenario. The following generic model parameters are proposed for calculations of local exposure outside the industrial site in the ECHA guidelines [28]:

- The total emissions are distributed radial symmetrically around the source (radius $1 \mathrm{~km}$ ).

- The height of the source is $10 \mathrm{~m}$.
- The average distance from the source to the boundary of the site is $100 \mathrm{~m}$.

- The concentration decreases linearly from the source to $1 \mathrm{~km}$.

These assumptions are used to calculate a generic local exposure scenario and therefore cannot be used to model a major accident at a specific site. In addition, they are not particle specific.

The input of ENM into surface water can occur in three ways:

1. Release into surface water through storm water collection systems along roads or on the production site or directly into surface water if there is a close proximity of the site of accident and the open water. In both cases, we have to assume that only a fraction of the total emitted ENM amount reaches the water. The probability to reach the water is higher for suspended ENM. However, washing of powdered ENM during rain events or with firefighting water cannot be excluded.

2. Release of ENM into wastewater with direct connection to surface water. Studies have shown that ENM are removed during wastewater treatment with a high efficiency [29]. However, during a shock load of antimicrobial ENM (e.g., silver), the bacterial population may be compromised and therefore the removal efficiency of the water treatment process [30].

3. Deposition from air. In this case, the input is dependent on the surface of the water body. Due to faster dilution, rivers are less at risk than lakes.

The ENM are diluted upon entry into the water bodies. The dilution de facto depends on the size of the water body and can have values between 1 and 100,000 [28]. A dilution factor of 10 is proposed if no other data are available. An additional dilution can result from the firefighting water.

Water contamination is even stronger dependent on the local situation than the emission into air. The probability for a contamination of surface waters that has to be classified as a major accident is therefore dependent on the proximity of the site of accident to the next freshwater body. An accident is considered as major when in a water volume of $10^{6} \mathrm{~m}^{3}$ the lethal concentration 50 $\left(\mathrm{LC}_{50}\right)$ and/or the acute half maximal effective concentration $\left(E_{50}\right)$ for fish or Daphnia, respectively, is surpassed [31]. With an $\mathrm{EC}_{50 \text { (Daphnia) }}$ of $1 \mu \mathrm{g} / \mathrm{l}$ [32] for nano-Ag and homogeneous distribution already, a release of $1 \mathrm{~kg}$ of nano-Ag could lead to the corresponding concentration. This evaluation neglects relevant elimination processes such as dissolution and precipitation as $\mathrm{AgCl}$; however, they may only play a role at longer time 
scales that are not relevant for major accident regulations. The contamination of natural waters can result in a secondary exposure of humans through bioaccumulation into fish. However, such long-term effects are not considered in major accident regulations.

A direct release of ENM into soils is only expected during transport accidents. Indirect transfer can occur through wet or dry deposition form air. Although the local soil concentration can be very high after a major accident, a persistent damage of the environment can be practically excluded due to the low particle mobility [33] and the possibility for soil remediation (excavation and landfilling of polluted soil).

\section{Toxicity and ecotoxicity in the framework of major accident prevention Human toxicity}

In the Swiss Ordinance on Major Accidents, the following criteria are used to determine the threshold amounts [1]:

- EU classification

- Acute toxicity; oral, dermal, and inhalation toxicities

- Classification given on MSDS

The comparison of conventional chemicals (e.g., microparticles) with ENM based on these criteria is restricted to the criterion 'acute toxicity' as the ENM have no special EU or MSDS classification. Table 1 summarizes the hazard potential of ENM to humans in comparison with conventional materials.
The published data are very heterogeneous and do not provide a clear effect pattern for each of the materials. The measured endpoint of the experimental data is not the lethal dose concentration $\left(\mathrm{LD}_{50}\right)$, but more subtoxic events such as inflammation, oxidative stress response, or gene expression profiling over different time scales were assessed, which make a sound comparison of the studies impossible. In addition, the three exposure routes (oral, dermal, and inhalation) provide different symptoms; therefore, the hazard potential of the selected materials is based more on an expert view than on standardized and comparable data sets.

\section{Ecotoxicity}

The ordinance of major accidents [1] uses as criteria for the evaluation of the ecotoxicity the $\mathrm{EC}_{50}$ for Daphnia (swimming disability after $24 \mathrm{~h}$ ) and the $\mathrm{LC}_{50}$ for fish (after 2 to 4 days). The only threshold in the area of ecotoxicity is at $2 \mathrm{t}$ of substance used at a site for an $\mathrm{EC}_{50}$ (Daphnia) or $\mathrm{LC}_{50}$ (fish) $<10 \mathrm{mg} / \mathrm{l}$. Tables 2 and 3 contrast $\mathrm{EC}_{50}$ and $\mathrm{LC}_{50}$ values for the nano- and microparticles $\left(\mathrm{TiO}_{2}\right)$ or dissolved metals $(\mathrm{Ag}, \mathrm{Zn})$. This comparison evaluates if the overall toxicity of the traditional form and the nano-form is different from each other. It does not consider any difference in the mode of action but simply uses mass as a metric to compare materials.

The only compound that is more critical in its nanoform than as dissolved metal is therefore $\mathrm{TiO}_{2}$ in its photocatalytically active form. For $\mathrm{Ag}$ and $\mathrm{ZnO}$, we cannot see a difference between the toxicity of the nano-form

Table 1 Hazard potential of ENM to humans in comparison with conventional materials (microparticles)

\begin{tabular}{|c|c|c|c|c|}
\hline \multirow[t]{2}{*}{ ENM } & \multicolumn{3}{|c|}{ Hazard potential $^{a}$} & \multirow[t]{2}{*}{ Remarks } \\
\hline & $\begin{array}{l}\text { Acute } \\
\text { toxicity }\end{array}$ & $\begin{array}{l}\text { Chronic } \\
\text { effects }\end{array}$ & $\begin{array}{c}\text { Difference } \\
\text { (micro/nano) }\end{array}$ & \\
\hline Nano- $\mathrm{TiO}_{2}$ & Very low & Low & 1:10 & $\begin{array}{l}\text { Although } \mathrm{TiO}_{2} \text { was placed in class } 3 \text { of the carcinogenic materials, its general toxicity is } \\
\text { low as shown by many recent studies. There is a difference in the effects of smaller and } \\
\text { larger particles, but this, for a release scenario during a major accident, is only of low } \\
\text { relevance [34-39] }\end{array}$ \\
\hline Nano-ZnO & Medium & Low & $1: 1$ & $\begin{array}{l}\text { Application of micro- or nanoscale ZnO particles into the lungs of mice or rats causes } \\
\text { a strong but intermediate inflammatory reaction. The strength as well as the course of } \\
\text { this reaction is practically identical for micro- or nanoscale } \mathrm{ZnO}[40,41] \text {. The acute } \\
\text { consequence of inhalation of Zn dust is zinc fever; however, for severe effects (deaths), } \\
\text { the concentration needs to surpass widely the permissible exposure limit of } 5 \mathrm{mg} / \mathrm{m}^{3}\end{array}$ \\
\hline CNT & Low & High & n.a. & $\begin{array}{l}\text { Dependent on the type of CNT (physicochemical properties, e.g., single-walled, multi-walled, } \\
\text { short/long), long-term effects similar to asbestos need to be considered (mesothelioma) } \\
\text { [42] if the conditions like for 'WHO fibers' (length }>5 \mu \mathrm{m} \text {, diameter }<3 \mu \mathrm{m} \text {, and a } \\
\text { length/diameter ratio of more than } 3: 1 \text { ) are given. So far, most industrially produced CNTs } \\
\text { are not considered to be WHO fibers [43-49] }\end{array}$ \\
\hline Nano-Ag & Low & Low & $1: 1$ & $\begin{array}{l}\text { Silver is used since many years in nanoparticulate form (colloidal silver). There is no } \\
\text { indication for an acute intoxication of humans with life-threatening degree, unless } \\
\text { there is exposure to ultrahigh concentrations. Because Ag particles are added in rather } \\
\text { small amounts to products, also the produced and transported amounts are rather } \\
\text { small and the risk of a major accident with fatal consequences is therefore limited [50-54] }\end{array}$ \\
\hline
\end{tabular}


Table $2 \mathrm{EC}_{50}$ values (mg/l) for Daphnia for different ENM: comparison between nano-form and microform/dissolved metals

\begin{tabular}{|c|c|c|c|}
\hline & \multicolumn{3}{|l|}{$\mathrm{EC}_{50}$ Daphnia } \\
\hline & $\begin{array}{l}\text { ENM lowest } \\
\text { reported } \\
\text { value }(\mathrm{mg} / \mathrm{l})\end{array}$ & $\begin{array}{l}\text { Larger particles } \\
\text { or dissolved } \\
\text { ions }^{d}\end{array}$ & $\begin{array}{l}\text { Rounded ratio } \\
\text { (nano/micro) }\end{array}$ \\
\hline Nano- $\mathrm{TiO}_{2}$ & $0.03[55]^{a}$ & $>100[56]$ & $\begin{array}{l}>1: 100 \text { (for the } \\
\text { photocatalytically } \\
\text { active form) }\end{array}$ \\
\hline Nano-ZnO & $0.62[57]^{b}$ & $1.86[58]^{e}$ & $1: 1$ \\
\hline CNT & $1.8[57]^{c}$ & - & - \\
\hline Nano-Ag & 0.001 [32] & 0.0015 [59] & 1:1 \\
\hline
\end{tabular}

a Other values (in mg/l): 0.8 [60], 3.8 [61]; bother values (in $\mathrm{mg} / \mathrm{l}$ ): 1 [56], 3.95 [62]; ' other value (in mg/l): 50.9 [63]; ${ }^{\mathrm{d}}$ for $\mathrm{Ag}$ and $\mathrm{ZnO}$, the values for the dissolved metals were taken; ${ }^{\mathrm{e}}$ other value (in $\mathrm{mg} / \mathrm{l}$, for micro-ZnO): 1 [56]

compared to the dissolved metals based on the currently available data. For CNT, we cannot make this comparison due to a missing larger particle.

\section{Preventive measures}

In the prevention of a major accident, a special emphasis should be placed on safety measures. This is especially important with downstream users. Whereas high safety measures are normally standard at production sites, especially in the chemical industry, the handling of ENM in manufacturing of the final products is much less controlled and can result in a much higher possibility for release $[7,72,73]$. An important step in this context is the employee training. The safe handling of ENM does not require more action than needed for the handling of powders and conventional chemicals.

Production and manufacturing sites have to comply with existing high safety standards, which are determined by the chemicals (e.g., solvents) that are used during the process. Special emphasis has to be placed on those companies that have no experience in handling conventional chemicals but were founded as pure 'nano'-company. A critical issue is the fact that downstream users of ENM do

Table 3 LC $_{50}$ values (mg/l) for fish for different ENM: comparison between nano-form and microform/dissolved metals

\begin{tabular}{|c|c|c|c|}
\hline & \multicolumn{3}{|l|}{$L C_{50}$ fish } \\
\hline & $\begin{array}{l}\text { ENM lowest } \\
\text { reported } \\
\text { value }(\mathrm{mg} / \mathrm{l})\end{array}$ & $\begin{array}{l}\text { Larger particles } \\
\text { or dissolved ions }\end{array}$ & $\begin{array}{l}\text { Rounded ratio } \\
\text { (nano/micro) }\end{array}$ \\
\hline Nano- $\mathrm{TiO}_{2}$ & $2[55]^{\mathrm{a}}$ & $>100$ [64] & $>1: 10$ \\
\hline Nano-ZnO & $1.8[65]^{b}$ & $1[58]^{f}$ & $1: 1$ \\
\hline CNT & $20[66]^{c}$ & - & - \\
\hline Nano-Ag & $0.025[67]^{d}$ & 0.003 [59] & 10:1 \\
\hline
\end{tabular}

a Other values: $125 \mathrm{mg} / \mathrm{l}$ [68], $500 \mathrm{mg} / \mathrm{l}$ [69]; ${ }^{\mathrm{b}}$ other value: $4.92 \mathrm{mg} / \mathrm{l}$ [68]; ' LOEC value, no $L C_{50}$ available; ${ }^{d}$ other values (in $\mathrm{mg} / \mathrm{l}$ ): 0.028 [32], 1.25 to $1.36 / 9.4$ to 10.6 [70], 7.07 [71]; ${ }^{\mathrm{e}}$ for $\mathrm{Ag}$ and $\mathrm{ZnO}$, the values for the dissolved metals were

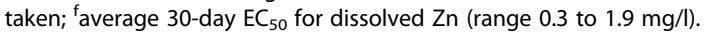

not have other information than those given in the MSDS, because these contain actually no nano-specific descriptions. However, these companies are likely to store only small amounts of ENM on their site - due to the high reactivity of the materials and the normally low concentrations used in final products - thus, the relevance for major accidents is seldom given.

\section{Constructional measures}

Constructional measures are indispensable for a safe handling of ENM. However, the established safety procedures used in the chemical industry are deemed to be sufficient. The procedural methods should be distinguished according to the specific form of the ENM. During production, manufacturing, and storage of suspended ENM, a detention basin is needed. The rooms should also not have any direct connection to the sewer system, or the connection needs to be equipped with a possibility for closure during an accident. For ENM in powder form, the ventilation and the configuration of the building envelope are central because they determine if ENM are released through damaged windows/ceilings or through ventilation into the environment. In both cases, fire prevention measures such as fire doors, separate storage rooms for organic solvents, and separate fire compartments are key.

\section{Technical measures}

Various technical measures can prevent or restrict a major accident. These include sprinklers in storage rooms, pressure-controlled equipment, and disconnection of ventilation in case of accident. However, these tools are not nano-specific but target the accident prevention of easily flammable compounds, which are stored in the same room. If these conventional measures are adopted consistently, they are also effective for ENM.

\section{Organizational measures}

Simple but effective organizational measures are access restrictions and sound employee trainings. All employees working with ENM should get an appropriate training and should be able to have access to personal protective equipment. The plant fire brigade or the local fire brigade should be informed about the presence of ENM and should be trained in suitable firefighting procedures.

\section{First insights of nanomaterials in major accident prevention}

The thresholds and criteria in the ordinance on major accident prevention [1] are based on the mass of the compound. Due to the small diameter of ENM, it is questioned if the approach of using a mass basis is adequate for ENM or if the particle number or specific surface area should to be taken instead. However, we 
consider a mass-based approach for ENM within major accident prevention regulation reasonable because data from (eco)toxicological studies are mainly mass-based. However, indispensable is in any case a clear definition of what an ENM and the proposition for a definition by the EU [74] clearly also influences the major accident regulation as this definition also covers natural and incidental nanomaterials and not only ENM $[75,76]$.

Solubility plays a central role for the assessment of the toxicity of ENM in comparison to microparticles. Nanoparticles of easily soluble materials such as $\mathrm{ZnO}$ or metals that can be oxidized and then release ions (e.g., Ag) dissolve, due to their small diameter and the corresponding high surface area, much faster than larger particles. Their toxicity should therefore be compared to that of the corresponding metal ions, e.g., $\mathrm{Zn}^{2+}$ and $\mathrm{Ag}^{+}$. The most important difference is that ENM can enter cells by additional pathways including passive entering into the cells comparable to the Trojan Horse mechanism. However, as shown in our evaluation of ecotoxicological data, the nano-form has overall not a higher toxicity than the dissolved form and thus, within the context of major accident prevention, the total mass of a compound, irrespective of its form, can be used.

In order to guarantee that all ENM are included in the existing major accident regulation, different options are possible (Table 4). In every case, the declaration of ENM on the MSDS is compulsory because without this information downstream users cannot assess if a company has reached a nano-specific threshold. It is also problematic that in certain intermediate products, the nanocontent is so low that it does not need to be specified in the list of ingredients.

In our opinion, option 2 is the best option for the following reasons:

- Classification 4 in Table 2 includes all ENM that will be produced in the future. The exemption list given in the Major Accident Ordinance does not need to be adapted continuously, and there is no danger that new, potentially toxic ENM are regulated by a too generic regulation not strict enough. The precautionary principle is applied.

- The classification is specific for each ENM. An over- or under-regulation is avoided and the specific properties of each ENM are considered. The importance of substance specificity is evident from the following considerations.

Despite a wide breadth of published studies, there are still many significant questions unanswered. The substancespecific factors that affect the toxicity of ENM have not yet been answered in a coherent manner [77]. In addition to the chemical composition, the following properties have been mentioned [78]: primary and secondary particle size; specific surface area; impurities or doting; surface properties (zeta potential, functionalization, coating); redox potential, reactivity; particle form; crystallinity; hydrophobicity/ hydrophilicity; solubility; biopersistency; age of particles.

In order to make any conclusions, all these factors need to be characterized and controlled in the studies. Additionally, particle-specific factors such as particle size distribution play a role. These considerations make clear that the terms 'CNT' and 'nano- $\mathrm{TiO}_{2}$ ' stand for a whole group of materials which can have very different properties, mainly due to shape, surface functionalization, or doting with other elements. It is, for example, assured that the toxicity of nano- $\mathrm{TiO}_{2}$ varies tremendously with changing mineral structure or surface coatings $[77,79]$.

For practical reasons, it will be difficult to perform (eco)toxicity tests for each produced or imported ENM. Producers need to be obligated to include the relevant information about toxicity and ecotoxicity of their product in the MSDS.

Based on our evaluation of the ENM, there is no special need for a drastic change in the classification of the

\section{Table 4 Overview on possible classifications for considering ENM in major accident regulations}

\begin{tabular}{|c|c|c|c|}
\hline & Rule & Advantage & Disadvantage \\
\hline 1 & $\begin{array}{l}\text { All ENM have the same (eco)toxicity as larger particles } \\
\text { with the same composition. Some specific ENM are } \\
\text { placed in the exemption list }\end{array}$ & $\begin{array}{l}\text { Simple rule; recognizes the higher } \\
\text { risk potential of certain ENM }\end{array}$ & Insufficient data to select exemptions \\
\hline 2 & $\begin{array}{l}\text { Each manufacturer has to provide specific (eco) } \\
\text { toxicological tests for each ENM, independent of } \\
\text { the chemical composition of the ENM }\end{array}$ & $\begin{array}{l}\text { The nano-aspect as well as the } \\
\text { different properties of various } \\
\text { ENM are considered }\end{array}$ & $\begin{array}{l}\text { Problem of definition of ENM; expensive for } \\
\text { companies that produce only small amounts } \\
\text { or small variations of materials }\end{array}$ \\
\hline 3 & $\begin{array}{l}\text { Dispersions are classified like normal chemicals; for } \\
\text { powders, a nano-specific regulation is implemented } \\
\text { in addition to existing regulations for powders }\end{array}$ & $\begin{array}{l}\text { The different risk of dispersions } \\
\text { and powders is accommodated. } \\
\text { Simple to define }\end{array}$ & $\begin{array}{l}\text { Possible exemptions need to be formulated } \\
\text { (see 1) }\end{array}$ \\
\hline 4 & $\begin{array}{l}\text { For ENM in powder form, the mass threshold is reduced } \\
\text { by a factor of } 10 \text { to accommodate the higher surface } \\
\text { area }\end{array}$ & $\begin{array}{l}\text { The precautionary principle and the } \\
\text { increased surface area of the } \\
\text { nanoparticles are considered }\end{array}$ & Relatively unspecific \\
\hline 5 & $\begin{array}{l}\text { ENM are categorized (e.g., soluble/insoluble, metal } \\
\text { oxides/metals/organic ENM) and assessed differently }\end{array}$ & $\begin{array}{l}\text { Differences between particle types } \\
\text { are considered }\end{array}$ & $\begin{array}{l}\text { Material-specific properties are over-represented; } \\
\text { many exemptions }\end{array}$ \\
\hline
\end{tabular}


materials, no matter if nano or not. According to the guidelines of the Major Accident Ordinance [80], currently, the following threshold values are valid for potentially nano-scaled compounds:

- 2,000 kg: $\mathrm{ZnO}, \mathrm{AgNO}_{3}$

- No threshold: $\mathrm{TiO}_{2}, \mathrm{SiO}_{2}$

- Not on the list: $\mathrm{CNT}, \mathrm{CeO}_{2}$, carbon black, $\mathrm{CaCO}_{3}$, metallic silver

- Case-specific evaluation needed: iron oxides, pigments

For CNT and all ENM for which their conventional counterpart is not on the list, we suggest that a casespecific classification has to be performed based on the criteria of the regulation [1]. The implementation of option 2 that is favored by us would result in a threshold limit of 2,000 kg for most nano-Ag and nano- $\mathrm{ZnO}$ compounds, corresponding to the currently effective limits for conventional $\mathrm{Ag}$ and $\mathrm{ZnO}$. For $\mathrm{CNT}$ and nano- $\mathrm{TiO}_{2}$, different threshold limits according to the specific properties of the ENM would come into force. Photocatalytic nano- $\mathrm{TiO}_{2}$ would get a threshold of $2,000 \mathrm{~kg}$ due to the increased toxicity against Daphnia. No threshold value would apply for non-photocatalytic nano- $\mathrm{TiO}_{2}$. For CNT, different thresholds would apply according to the length and stiffness of the fibers. Option 2 thus allows a differentiated regulation of all ENM, under the precondition that a clear definition for ENM and the duty for declaration in the MSDS exists.

\section{Conclusions}

As a general conclusion, we can state that ENM are clearly less hazardous than many other chemicals, e.g., solvents or high-reactivity compounds such as certain pharmaceuticals, and can be treated similar to dusts or pigments. However, it is extremely important to note that this conclusion is only valid in relation to major accidents and not for occupational and environmental health or product safety, i.e., the exposure of workers inside the factory premises or of consumers due to products containing ENM. It also does not consider long-term environmental effects due to release during the use of the products. These issues are covered in separate regulations that are not part of our evaluation.

Due to the limited fundamental understanding of ENM fate and effects, our conclusions need to be taken with caution. Until standardized tests for the determination of ENM toxicity are available and the declaration of ENM on the MSDS is standard, it is recommended to perform at regular intervals a monitoring regarding new 'high production volume ENM' and to check if the statements made in this work are still valid. Nevertheless, the multitude of different studies that exist for the ENM considered in this work and that report relevant results show in general no evidence for a specific need for action. The acute risks of ENM within a major accident are not significantly different from conventional compounds, implying that the current regulation for major accidents is also able to cover ENM.

\section{Competing interests}

The authors declare that they have no competing interests.

\section{Authors' contributions}

All authors contributed equally to this work. All authors read and approved the final manuscript.

\section{Acknowledgements}

This study was financed by the Swiss Federal Office for the Environment. An extended report is available at www.bafu.admin.ch/uw-1301-e. Data from the DaNa website have been used for the evaluation (BMBF; project DaNa No 03X0075A; www.nanoobjects.info).

Received: 13 November 2013 Accepted: 15 January 2014

Published: 23 January 2014

\section{References}

1. CH: Verordnung über den Schutz vor Störfällen, 27. Februar 1991. Bern: Swiss Federal Council; 2008.

2. Steinkrauss M, Fierz H, Lerena P, Suter G: Brand - und Explosionseigenschaften synthetischer Nanomaterialien - Erste Erkenntnisse für die Störfallvorsorge. Bern: Herausgegeben vom Bundesamt für Umwelt (BAFU); 2010.

3. Holbrow P, Wall M, Sanderson E, Bennett D, Rattigan W, Bettis R, Gregory D: Fire and Explosion Properties of Nanopowders. RR782 Research Report. Buxton: Health and Safety Laboratory; 2010.

4. European Commission: Mitteilung der Kommission an das europäische Parlament, den Rat und den europäischen Wirtschafts- und Sozialausschuss, Regelungsaspekte bei Nanomaterialien. [http://eur-lex.europa.eu/Notice.do? mode $=\mathrm{db} \mid \&$ lang=en\&ihmlang=en\&lng1=en,de\&lng2=bg,cs, da, de,el,en,es,et, 1 i,fr, hu,it,lt,lv,mt,nl,pl,pt,ro,sk,sl,sv,\&val=472573:cs\&page=]

5. SRU: Vorsorgestrategien für Nanomaterialien. Berlin: Sondergutachten des Sachverständigenrats für Umweltfragen; 2011.

6. Kittel G: Leitfaden für das Risikomanagement beim Umgang mit Nanomaterialien am Arbeitsplatz, November 2010. Vienna: Bundesministerium für Arbeit, Soziales und Konsumentenschutz (Wien) im Rahmen des Österreichische Arbeitsschutzstragegie 2007-2012; 2010.

7. Pistner C: Eco@Work. [http://www.oeko.de/103/wissen2]

8. UK: Draft Directive on the control of major accident hazards involving dangerous substances, 14 December 2011. [http://www.publications. parliament.uk/pa/cm201012/cmselect/cmeuleg/428-xliv/42808.htm]

9. BSI: Nanotechnologies - Part 2: Guide to Safe Handling and Disposal of Manufactured Nanomaterials. London: British Standards Institute; 2007.

10. OECD: Organisation for Economic Co-operation and Development: Environment Directorate Chemicals Committee. Risk of Major Accidents Involving Nanomaterials - Prevention of, Preparedness for and Response to Accidents. Paris: Organisation for Economic Co-operation and Development; 2011

11. Piccinno F, Gottschalk F, Seeger S, Nowack B: Industrial production quantities and uses of ten engineered nanomaterials for Europe and the world. J Nanopart Res 2012, 14:1109.

12. Kuhlbusch TAJ, Asbach C, Fissan H, Gohler D, Stintz M: Nanoparticle exposure at nanotechnology workplaces: a review. Part Fibre Toxicol 2011, $8: 22$.

13. Fendler R, Kleiber M, Watorowski J: Jahresbericht 2008; Zentrale Melde- und Auswertestelle für Störfälle und Störungen in verfahrenstechnischen Anlagen (ZEMA), Umweltbundesamt Dessau. [http://www.uba.de/ubainfo-medien/4130.html]

14. Krausmann E, Cozzani V, Salzano E, Renni E: Industrial accidents triggered by natural hazards: an emerging risk issue. Nat Hazards Earth System Sci 2011, 11:921-929.

15. Krausmann E, Renni E, Campedel M, Cozzani V: Industrial accidents triggered by earthquakes, floods and lightning: lessons learned from a database analysis. Nat Hazards 2011, 59:285-300. 
16. Raab C, Simkó M, Fiedeler U, Nentwich M, Gazsó A: Herstellungsverfahren von Nanopartikeln und Nanomaterialien. Nano Trust - Dossiers 2008 6. doi:10.1553/ITA-nt-006

17. Keller A, McFerran S, Lazareva A, Suh S: Global life cycle releases of engineered nanomaterials. J Nanoparticle Res 2013, 15:1-17.

18. L'Alsace [http://www.lalsace.fr/actualite/2011/10/10/vieux-thann-des-sacs-doxyde-detitane-tombent-d-un-camion-sur- la-rn66]

19. Pan B, Xing BS: Applications and implications of manufactured nanoparticles in soils: a review. Eur J Soil Sci 2012, 63:437-456.

20. Johnston JM, Lowry M, Beaulieu S, Bowles E: State-of-the-Science Report on Predictive Models and Modeling Approaches for Characterizing and Evaluating Exposure to Nanomaterials. EPA/600/R-10/129. Athens: U.S. Environmental Protection Agency, Office of Research and Development; 2010.

21. Gottschalk F, Sonderer T, Scholz RW, Nowack B: Modeled environmental concentrations of engineered nanomaterials $\left(\mathrm{TiO}_{2}, \mathrm{ZnO}, \mathrm{Ag}, \mathrm{CNT}\right.$, fullerenes) for different regions. Environ Sci Technol 2009, 43:9216-9222.

22. Mueller NC, Nowack B: Exposure modeling of engineered nanoparticles in the environment. Environ Sci Technol 2008, 42:4447-4453.

23. Seipenbusch M, Binder A, Kasper G: Temporal evolution of nanoparticle aerosols in workplace exposure. Ann Occup Hyg 2008, 52:707-716.

24. Demou E, Peter P, Hellweg S: Exposure to manufactured nanostructured particles in an industrial pilot plant. Ann Occup Hyg 2008, 52:695-706.

25. Walser T, Hellweg S, Juraske R, Luechinger NA, Wang J, Fierz M: Exposure to engineered nanoparticles: model and measurements for accident situations in laboratories. Sci Total Environ 2012, 420:119-126.

26. Buseck PR, Adachi K: Nanoparticles in the atmosphere. Elements 2008, 4:389-394.

27. OECD: Joint Meeting of the Chemicals Committee and the Working Party on Chemicals, Pesticides and Biotechnology - Report of the WPMN Expert Meeting on Inhalation Toxicity Testing for Nanomaterials. Paris: Organisation for Economic Co-operation and Development; 2012.

28. ECHA: Guidance on Information Requirements and Chemical Safety Assessment. Helsinki: European Chemicals Agency; 2008.

29. Westerhoff PK, Kiser A, Hristovski K: Nanomaterial removal and transformation during biological wastewater treatment. Environ Eng Sci 2013, 30:109-117.

30. Mu H, Zheng $X$, Chen YG, Chen H, Liu K: Response of anaerobic granular sludge to a shock load of zinc oxide nanoparticles during biological wastewater treatment. Environ Sci Technol 2012, 46:5997-6003.

31. BUWAL: Beurteilungskriterien I zur Störfallverordnung StFV, Richtlinien für Betriebe mit Stoffen, Erzeugnissen oder Sonderabfällen. Bern: Swiss Federal Office for the Environment; 1996.

32. Kim J, Kim S, Lee S: Differentiation of the toxicities of silver nanoparticles and silver ions to the Japanese medaka (Oryzias latipes) and the cladoceran Daphnia magna. Nanotoxicology 2011, 5:208-214.

33. Grieger KD, Fjordboge A, Hartmann NB, Eriksson E, Bjerg PL, Baun A: Environmental benefits and risks of zero-valent iron nanoparticles ( $\mathrm{nZVI}$ ) for in situ remediation: risk mitigation or trade-off? J Contam Hydrol 2010, 118:165-183.

34. NanoCare: Health Related Aspects of Nanomaterials. Final Scientific Report. Frankfurt am Main: DECHEMA; 2009

35. Tang M, Zhang T, Xue Y, Wang S, Huang M, Yang Y, Lu M, Lei H, Kong L, Yuepu P: Dose dependent in vivo metabolic characteristics of titanium dioxide nanoparticles. J Nanosci Nanotechnol 2010, 10:8575-8583.

36. Kobayashi N, Naya M, Endoh S, Maru J, Yamamoto K, Nakanishi J: Comparative pulmonary toxicity study of nano- $\mathrm{TiO}_{2}$ particles of different sizes and agglomerations in rats: different short- and long-term post-instillation results. Toxicology 2009, 264:110-118.

37. Park E-J, Yoon J, Choi K, Yi J, Park K: Induction of chronic inflammation in mice treated with titanium dioxide nanoparticles by intratracheal instillation. Toxicology 2009, 260:37-46

38. Li J, Li Q, Xu J, Li J, Cai X, Liu R, Li Y, Ma J, Li W: Comparative study on the acute pulmonary toxicity induced by 3 and $20 \mathrm{~nm} \mathrm{TiO}$. primary particles in mice. Environ Toxicol Pharmacol 2007, 24:239-244.

39. Ma-Hock L, Burkhardt S, Strauss V, Gamer AO, Wiench K, van Ravenzwaay B, Landsiedel R: Development of a short-term inhalation test in the rat using nano-titanium dioxide as a model substance. Inhal Toxicol 2009, 21:102-118.

40. Sayes CM, Reed KL, Warheit DB: Assessing toxicity of fine and nanoparticles: comparing in vitro measurements to in vivo pulmonary toxicity profiles. Toxicol Sci 2007, 97:163-180.

41. Warheit DB, Sayes CM, Reed KL: Nanoscale and fine zinc oxide particles: can in vitro assays accurately forecast lung hazards following inhalation exposures? Environ Sci Technol 2009, 43:7939-7945.
42. Donaldson K, Murphy F, Duffin R, Poland C: Asbestos, carbon nanotubes and the pleural mesothelium: a review of the hypothesis regarding the role of long fibre retention in the parietal pleura, inflammation and mesothelioma. Part Fibre Toxicol 2010, 7:5

43. Murphy F, Schinwald A, Poland C, Donaldson K: The mechanism of pleural inflammation by long carbon nanotubes: interaction of long fibres with macrophages stimulates them to amplify pro-inflammatory responses in mesothelial cells. Part Fibre Toxicol 2012, 9:8

44. Bianco A, Kostarelos K, Prato M: Applications of carbon nanotubes in drug delivery. Curr Opin Chem Biol 2005, 9:674-679.

45. Deng $X$, Jia G, Wang $H$, Sun $H$, Wang $X$, Yang S, Wang T, Liu Y: Translocation and fate of multi-walled carbon nanotubes in vivo. Carbon 2007, 45:1419-1424.

46. Pantarotto $D$, Singh $R$, McCarthy $D$, Erhardt $M$, Briand JP, Prato M, Kostarelos K, Bianco A: Functionalized carbon nanotubes for plasmid DNA gene delivery. Angew Chem Int Ed 2004, 43:5242-5246.

47. Qu G, Bai Y, Zhang Y, Jia Q, Zhang W, Yan B: The effect of multiwalled carbon nanotube agglomeration on their accumulation in and damage to organs in mice. Carbon 2009, 47:2060-2069.

48. Wang H, Wang J, Deng X, Sun H, Shi Z, Gu Z, Liu Y, Yuliang Z: Biodistribution of carbon single-wall carbon nanotubes in mice. J Nanosci Nanotechnol 2004, 4:1019-1024

49. Yang ST, Guo W, Lin Y, Deng XY, Wang HF, Sun HF, Liu YF, Wang X, Wang W, Chen M, Huang YP, Sun YP: Biodistribution of pristine single-walled carbon nanotubes in vivo. J Phys Chem C 2007, 111:17761-17764.

50. Wijnhoven SWP, Peijnenburg WJGM, Herberts CA, Hagens WI, Oomen AG, Heugens EHW, Roszek B, Bisschops J, Gosens I, Van De Meent D, Dekkers S, De Jong WH, van Zijverden M, Sips AJAM, Geertsma RE: Nano-silver - a review of available data and knowledge gaps in human and environmental risk assessment. Nanotoxicology 2009, 3:109-138.

51. Kim YS, Kim JS, Cho HS, Rha DS, Kim JM, Park JD, Choi BS, Lim R, Chang HK, Chung YH, Kwon $1 \mathrm{H}$, Jeong J, Han BS, Yu IJ: Twenty-eight-day oral toxicity, genotoxicity, and gender-related tissue distribution of silver nanoparticles in Sprague-Dawley rats. Inhal Toxicol 2008, 20:575-583.

52. Ji JH, Jung JH, Kim SS, Yoon J-U, Park JD, Choi BS, Chung YH, Kwon IH, Jeong J, Han BS, Shin JH, Sung JH, Song KS, Yu IJ: Twenty-eight-day inhalation toxicity study of silver nanoparticles in Sprague-Dawley rats. Inhal Toxicol 2007, 19:857-871.

53. NanoTrust: Dossier No10: Nanosilber. [http://nanotrust.ac.at/dossiers.html]

54. Möller M, Eberle U, Hermann A, Moch K, Stratmann B: Nanotechnologie im Bereich der Lebensmittel. Bern: TA-SWISS (hrsg) - Zentrum für Technologiefolgen-Abschätzung; 2009.

55. Ma HB, Brennan A, Diamond SA: Phototoxicity of $\mathrm{TiO}_{2}$ nanoparticles under solar radiation to two aquatic species: Daphnia magna and Japanese medaka. Environ Toxicol Chem 2012, 31:1621-1629.

56. Wiench K, Wohlleben W, Hisgen V, Radke K, Salinas E, Zok S, Landsiedel R: Acute and chronic effects of nano- and non-nano-scale $\mathrm{TiO} 2$ and $\mathrm{ZnO}$ particles on mobility and reproduction of the freshwater invertebrate Daphnia magna. Chemosphere 2009, 76:1356-1365.

57. Zhu XS, Zhu L, Chen YS, Tian SY: Acute toxicities of six manufactured nanomaterial suspensions to Daphnia magna. J Nanopart Res 2009, 11:67-75.

58. De Schamphelaere KAC, Lofts S, Janssen CR: Bioavailability models for predicting acute and chronic toxicity of zinc to algae, daphnids, and fish in natural surface waters. Environ Toxicol Chem 2005, 24:1190-1197.

59. Ratte HT: Bioaccumulation and toxicity of silver compounds: a review. Environ Toxicol Chem 1999, 18:89-108.

60. Amiano I, Olabarrieta J, Vitorica J, Zorita S: Acute toxicity of nanosized $\mathrm{TiO}_{2}$ to Daphnia magna under UVA irradiation. Environ Toxicol Chem 2012, 31:2564-2566.

61. Dabrunz A, Duester L, Prasse C, Seitz F, Rosenfeldt R, Schilde C, Schaumann $\mathrm{GE}$, Schulz R: Biological surface coating and molting inhibition as mechanisms of $\mathrm{TiO}(2)$ nanoparticle toxicity in Daphnia magna. PLoS One 2011, 6. doi:10.1371/journal.pone.0020112.

62. Blinova I, Ivask A, Heinlaan M, Mortimer M, Kahru A: Ecotoxicity of nanoparticles of $\mathrm{CuO}$ and $\mathrm{ZnO}$ in natural water. Environ Pollut 2010, 158:41-47.

63. Kennedy AJ, Hull MS, Steevens JA, Dontsova KM, Chappell MA, Gunter JC, Weiss CA: Factors influencing the partitioning and toxicity of nanotubes in the aquatic environment. Environ Toxicol Chem 2008, 27:1932-1941.

64. Kronos: Material satefy data sheet for KRONOS titanium dioxide (all types). [http://kronostio2.com/en/data-sheets-and-literature/safetydatasheets/finish/93/338] 
65. Zhu XS, Zhu L, Duan ZH, Qi RQ, Li Y, Lang YP: Comparative toxicity of several metal oxide nanoparticle aqueous suspensions to Zebrafish (Danio rerio) early developmental stage. J Environ Sci Health Part Toxic/ Hazard Subst Environ Eng 2008, 43:278-284.

66. Cheng JP, Flahaut E, Cheng SH: Effect of carbon nanotubes on developing zebrafish (Danio rerio) embryos. Environ Toxicol Chem 2007, 26:708-716.

67. Asharani PV, Wu YL, Gong ZY, Valiyaveettil S: Toxicity of silver nanoparticles in zebrafish models. Nanotechnology 2008, 19:255102.

68. Xiong DW, Fang T, Yu LP, Sima XF, Zhu WT: Effects of nano-scale TiO(2), $\mathrm{ZnO}$ and their bulk counterparts on zebrafish: acute toxicity, oxidative stress and oxidative damage. Sci Total Environ 2011, 409:1444-1452.

69. Hall S, Bradley T, Moore JT, Kuykindall T, Minella L: Acute and chronic toxicity of nano-scale $\mathrm{TiO}(2)$ particles to freshwater fish, cladocerans, and green algae, and effects of organic and inorganic substrate on $\mathrm{TiO}(2)$ toxicity. Nanotoxicology 2009, 3:91-97.

70. Laban G, Nies L, Turco R, Bickham J, Sepúlveda M: The effects of silver nanoparticles on fathead minnow (Pimephales promelas) embryos. Ecotoxicology 2010, 19:185-195.

71. Griffitt RJ, Luo J, Gao J, Bonzongo JC, Barber DS: Effects of particle composition and species on toxicity of metallic nanomaterials in aquatic organisms. Environ Toxicol Chem 2008, 27:1972-1978.

72. Som C, Berges M, Chaudhry Q, Dusinska M, Fernandes TF, Olsen SI, Nowack $B$ : The importance of life cycle concepts for the development of safe nanoproducts. Toxicology 2010, 269:160-169.

73. Kuhlbusch T, Nickel C: Emission von Nanopartikeln aus ausgewählten Produkten in ihrem Lebenszyklus, Umweltbundesamt Dessau. [http://www.uba.de/uba-info-medien/4028.html]

74. EU: Commission Recommendation of 18 October 2011 on the Definition of Nanomaterial (2011/696/EU). O. J. L 275: 38-40. Brussels: European Union; 2011.

75. Lövestam G, Rauscher H, Roebben G, Sokull Klüttgen B, Gibson N, Putaud JP, Stamm H: Considerations on a Definition of Nanomaterial for Regulatory Purposes. Luxembourg: Publications Office of the European Union; 2010. doi:10.2788/98686

76. Bleeker EAJ, Cassee FR, Geertsma RE, Jong WH, Heugens EHW, Koers Jacquemijns M, Meent D, Oomen AG, Popma J, Rietveld AG, Wijnhoven SWP: Interpretation and Implications of the European Commission Recommendation on the Definition of Nanomaterial, RIVM Letter Report 601358001/2012. Bilthoven: National Institute for Public Health and the Environment; 2012

77. Menard A, Drobne D, Jemec A: Ecotoxicity of nanosized TiO(2). Review of in vivo data. Environ Pollut 2011, 159:677-684.

78. Ostiguy C, Roberge B, Ménard L, Endo CA: Best practices guide to synthetic nanoparticle risk management; Institut de recherche Robert-Sauvé en santé et en sécurité du travail (IRSST), Commission de la santé et de la sécurité du travail du Québec (CSST) and NanoQuébec; REPORT R-599, Montréal. [http://www.irsst.qc.ca]

79. Auffan M, Pedeutour M, Rose J, Masion A, Ziarelli F, Borschneck D, Chaneac C, Botta C, Chaurand P, Labille J, Bottero JY: Structural degradation at the surface of a $\mathrm{TiO}_{2}$-based nanomaterial used in cosmetics. Environ Sci Technol 2010, 44:2689-2694.

80. BAFU BfU: Mengenschwellen gemäss Störfallverordnung (StFV) - Liste mit Stoffen und Zubereitungen. Bern: Swiss Federal Office for the Environment; 2006.

doi:10.1186/2190-4715-26-2

Cite this article as: Nowack et al: How to consider engineered nanomaterials in major accident regulations? Environmental Sciences Europe 2014 26:2.

\section{Submit your manuscript to a SpringerOpen ${ }^{\odot}$ journal and benefit from:}

- Convenient online submission

- Rigorous peer review

- Immediate publication on acceptance

- Open access: articles freely available online

- High visibility within the field

- Retaining the copyright to your article 